University of Nebraska - Lincoln

DigitalCommons@University of Nebraska - Lincoln

Publications from USDA-ARS / UNL Faculty

U.S. Department of Agriculture: Agricultural

Research Service, Lincoln, Nebraska

2005

\title{
Trichinella nativa in a black bear from Plymouth, New Hampshire
}

D.E. Hill

Animal Parasitic Diseases Laboratory, dhill@anri.barc.usda.gov

H.R. Gamble

National Academy of Sciences, Washington

D.S. Zarlenga

Animal Parasitic Diseases Laboratory \& Bovine Functions and Genomics Laboratory

C. Cross

Animal Parasitic Diseases Laboratory

J. Finnigan

New Hampshire Public Health Laboratories, Concord

Follow this and additional works at: https://digitalcommons.unl.edu/usdaarsfacpub

Hill, D.E.; Gamble, H.R.; Zarlenga, D.S.; Cross, C.; and Finnigan, J., "Trichinella nativa in a black bear from Plymouth, New Hampshire" (2005). Publications from USDA-ARS / UNL Faculty. 2244.

https://digitalcommons.unl.edu/usdaarsfacpub/2244

This Article is brought to you for free and open access by the U.S. Department of Agriculture: Agricultural Research Service, Lincoln, Nebraska at DigitalCommons@University of Nebraska - Lincoln. It has been accepted for inclusion in Publications from USDA-ARS / UNL Faculty by an authorized administrator of DigitalCommons@University of Nebraska - Lincoln. 


\title{
Trichinella nativa in a black bear from Plymouth, New Hampshire
}

\author{
D.E. Hill ${ }^{\text {a, }}$, H.R. Gamble ${ }^{\mathrm{c}}$, D.S. Zarlenga ${ }^{\mathrm{a}, \mathrm{b}}$, C. Coss $^{\mathrm{a}}$, J. Finnigan ${ }^{\mathrm{d}}$ \\ ${ }^{a}$ United States Department of Agriculture, Agricultural Research Service, Animal and Natural Resources Institute, \\ Animal Parasitic Diseases Laboratory, Building 1044, BARC-East, Beltsville, MD 20705, USA \\ ${ }^{\mathrm{b}}$ Bovine Functions and Genomics Laboratory, Building 1044, BARC-East, Beltsville, MD 20705, USA \\ ${ }^{\mathrm{c}}$ National Academy of Sciences, Washington, DC, USA \\ ${ }^{\mathrm{d}}$ The Food Safety Microbiology Unit, New Hampshire Public Health Laboratories, Concord, NH, USA
}

\begin{abstract}
A suspected case of trichinellosis was identified in a single patient by the New Hampshire Public Health Laboratories in Concord, NH. The patient was thought to have become infected by consumption of muscle larvae (ML) in undercooked meat from a black bear killed in Plymouth, NH in October 2003 and stored frozen at $-20{ }^{\circ} \mathrm{C}$ fro 4 months. In January 2004 , a $600 \mathrm{~g}$ sample of the meat was thawed at $4{ }^{\circ} \mathrm{C}$, digested in hydrochloric acid and pepsin, and larvae were collected by sedimentation. Intact, coiled, and motile ML were recovered (366 larvae per gram (lpg) of tissue), which were passed into mice and pigs. Multiplex PCR revealed a single $127 \mathrm{bp}$ amplicon, indicative of Trichinella nativa. The Reproductive Capacity Index (RCI) for the T. nativa-Plymouth isolate in mice was 24.3. Worm burdens in the diaphragms of two 3-month-old pigs given $2500 \mathrm{ML}$ were 0.05 and $0.2 \mathrm{lpg}$ by 35 days post-inoculation, while 2.2 and $0.75 \mathrm{lpg}$ were recovered from two 3-month-old pigs given $10,000 \mathrm{ML}$; no larvae were recovered from four 1-year-old pigs given $2500 \mathrm{ML}(n=2)$ or 10,000 ML $(n=2)$. Viable larvae were also recovered from frozen black bear meat harvested at two additional locations, one in southern Ontario, Canada, and one in upstate New York, USA. Multiplex PCR using genomic DNA from these parasite samples demonstrated that both isolates were T. nativa. This is the first report of the freeze-resistant species, T. nativa, within the continental United States.

Published by Elsevier B.V.
\end{abstract}

Keywords: Trichinella nativa; zoonosis; uncooked meat; Ursus americanus

\section{Introduction}

Sylvatic isolates of the genus Trichinella are widespread in the environment due to an expansive host range and worldwide geographic distribution.

\footnotetext{
* Corresponding author. Tel.: +1 301504 8770; fax: +1 3015046273 .

E-mail address: dhill@anri.barc.usda.gov (D.E. Hill).
}

Though Trichinella spiralis is virtually absent from the U.S. pig population (NAHMS, 2000, unpublished), sylvatic isolates pose a risk for zoonotic transmission when wildlife has access to pig barns or non-confined animals. In addition, game animals serve as hosts for Trichinella species that can cause human disease if meats are not properly prepared.

Currently, eight sibling species and two genotypes of undetermined taxonomic status have been identified 
in the genus Trichinella (Kapel, 2000; Murrell et al., 2000; La Rosa et al., 2003). Geographic distribution of these isolates has been described (Pozio et al., 1992; Kapel, 1997; Pozio et al., 1998; Pozio, 2001a,b). Two of the sibling species, Trichinella nativa and Trichinella $\mathrm{T} 6$ have been identified as freeze tolerant and are capable of surviving in frozen muscle tissues for extended periods of time at temperatures from -5 to $-18{ }^{\circ} \mathrm{C}$ (Kapel et al., 1999; Malakauskas and Kapel, 2003). Trichinella T6 has been identified in cougar and other carnivores from the Rocky Mountain region of the western continental United States, Pennsylvania, and Ontario, Canada (Dworkin et al., 1996). T. nativa, on the other hand, was thought to be confined to the arctic and subarctic zones of the Holarctic region (Murrell et al., 2000) and has not been previously reported within the continental United States or in areas where the January isotherm is higher than $-5{ }^{\circ} \mathrm{C}$ (Pozio et al., 1998). In this study, we describe an apparent southern geographic extension of the known range of $T$. nativa into the continental United States.

\section{Materials and methods}

Approximately $1.5 \mathrm{~kg}$ of frozen black bear meat was received at the Animal Parasitic Diseases Laboratory, Beltsville, MD, in December 2003. The bear meat had been frozen for at least 6 weeks and was kept frozen at $-20{ }^{\circ} \mathrm{C}$ until January 2004. Coiled intracellular larvae were noted on compression slides. Pepsin: $\mathrm{HCl}$ digestion (Gamble, 1996) of the bear meat revealed live, motile larvae which were washed by centrifugation. Five groups of 5 mice (Swiss-Webster females, Taconic Farms, Germantown, NY) were orally inoculated with $500,1000,1500,2000$, and 2500 muscle larvae (ML) each. After 21 days, larvae were recovered from skinned, eviscerated carcasses by pepsin: $\mathrm{HCl}$ digestion, enumerated, and photographed using an Olympus BX-2 digital photomicroscope.

The reproductive capacity index $(\mathrm{RCI}=\# \mathrm{ML}$ recovered/\#ML inoculated) was determined in two groups of 10 mice inoculated with 50 or $100 \mathrm{ML}$ and digested 35 days later as described above. The RCI index in pigs was determined by inoculating two groups of four pigs (Group 1: 1 year in age; Group 2: 3 months in age) with 2500 or 10,000 larvae. Thirty-five days after inoculation, $100 \mathrm{~g}$ samples from tongue, diaphragm, loin, tail $(50 \mathrm{~g})$, shoulder, quadriceps, hams, shanks (front), masseter, intercostals, neck, tenderloin, flank, and throat were collected from each pig, weighed, digested, and worm burdens were determined. In addition, serum was collected from each pig at necropsy for ELISA (Gamble et al., 1997).

For multiplex PCR, ML recovered from the naturally infected bear meat, and experimentally infected mice and pigs, were each washed three times in Hanks Balanced Salt Solution, pelleted, and subjected to genomic DNA extraction utilizing a DNeasy Tissue Kit (Qiagen Inc., Valencia, CA). The multiplex PCR was carried out essentially as described by Zarlenga et al. (1999).

During the same approximate time period, viable ML were obtained from two additional frozen black bear meat samples obtained (1) through a custom slaughterhouse in Clinton County, New York, and (2) from an animal shot and field dressed in Timmons, Ont., Canada, prior to transporting the meat to Tennessee. Multiplex PCR was carried out on DNA isolated from each parasite sample as described above.

\section{Results}

All mice survived the inoculation of 500-2500 larvae recovered from the New Hampshire bear meat. Infection efficiencies determined from mice inoculated with 50 or $100 \mathrm{ML}$ resulted in mean larval worm burdens of $1260( \pm 735)$ and $2340( \pm 1458)$, respectively, and a mean RCI of 24.3. A single larva only was recovered from throat muscle of one pig in Group 1 (1 year of age) inoculated with 10,000 ML. No other larvae were recovered from Group 1 pigs. Viable ML were recovered from all four pigs in Group 2 (3 months of age) (Table 1). Pigs in Group 2 had a calculated worm burden of 0.05 and $0.2 \mathrm{lpg}$ in animals inoculated with $2500 \mathrm{ML}$, and 2.2 and $0.75 \mathrm{lpg}$ in animals inoculated with 10,000 ML. All pigs in both groups had high antibody titers to T. nativa $\mathrm{E} / \mathrm{S}$ products in ELISA (Table 2).

Multiplex PCR revealed amplicons of the expected size (127 bp) for T. nativa in assays containing DNA from the naturally infected bear and from the experimentally infected pigs (Fig. 1). Multiplex PCR analysis of Trichinella isolates from both Clinton 
Table 1

Recovery of muscle larvae (ML) from 3-month-old pigs ${ }^{\mathrm{a}}$

\begin{tabular}{lcc}
\hline Muscle & $2500 \mathrm{ML}$ (pig 5/6) & $10,000 \mathrm{ML}$ (pig 7/8) \\
\hline Diaphragm & $10 / 40$ & $220 / 74$ \\
Intercostal & $0 / 40$ & $58 / 38$ \\
Taib $^{\mathrm{b}}$ & $0 / 10$ & $5 / 0$ \\
Shoulder & $0 / 10$ & $134 / 11$ \\
Tongue & $10 / 50$ & $216 / 53$ \\
Quadriceps & $0 / 10$ & $20 / 4$ \\
Ham & $0 / 0$ & $28 / 6$ \\
Shank-front & $20 / 0$ & $0 / 7$ \\
Mandibular & $0 / 10$ & $70 / 10$ \\
Neck & $0 / 40$ & $180 / 97$ \\
Loin & $10 / 0$ & $20 / 6$ \\
Tenderloin & $0 / 40$ & $140 / 62$ \\
Flank & $1 / 30$ & $96 / 28$ \\
Throat & $0 / 0$ & $70 / 25$ \\
\hline
\end{tabular}

a Total larvae recovered from $100 \mathrm{~g}$ muscle samples.

b Total larvae recovered from $50 \mathrm{~g}$ muscle samples.

County, NY, and Timmons, Ont., also revealed a single $127 \mathrm{bp}$ amplicon, indicative of T. nativa. Muscle larvae were deposited with the International Trichinella Reference Center in Rome, Italy, and assigned the number ISS1552.

\section{Discussion}

Based upon its resistance to freezing and the amplification of a single $127 \mathrm{bp}$ target sequence in multiplex PCR assays, the isolate obtained from Plymouth, NH and described herein is T. nativa. The black bear, Ursus americanus, is territorial and will generally occupy an area usually $8-10$ mile $^{2}(20-$ $25 \mathrm{~km}^{2}$ ), though in less populated locations they may extend their range to over 15 mile $^{2}\left(40 \mathrm{~km}^{2}\right)$. Thus, this limited range suggests that the animal taken in Plymouth, New Hampshire likely originated within

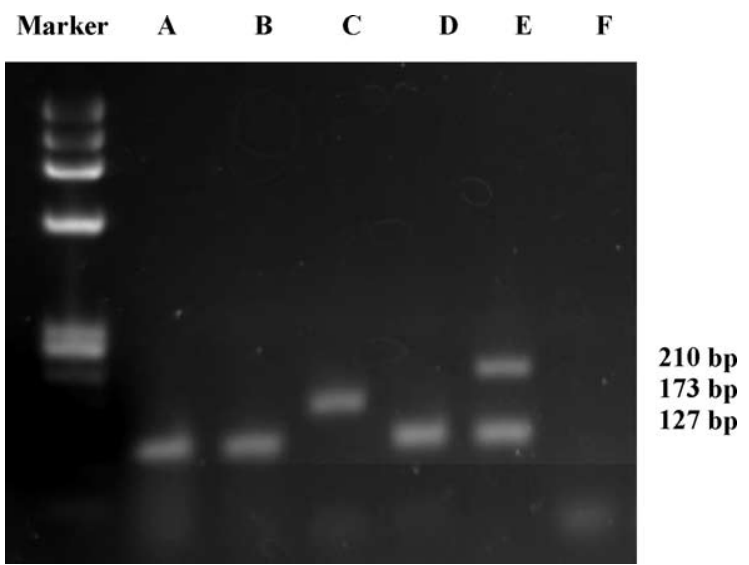

Fig. 1. Multiplex PCR for differentiating Trichinella genotypes (Zarlenga et al., 1999). (A) T. nativa-Plymouth isolate from experimentally infected pig, $127 \mathrm{bp}$; (B) T. nativa-Plymouth isolate from naturally infected black bear; (C) T. spiralis isolate ISS31 control; (D) T. nativa isolate ISS43 control; (E) Trichinella T6 isolate ISS46 control; (F) negative control.

United States boundaries making this the first report of T. nativa obtained from hosts living within the continental United States; however, aberrant migration patterns cannot be ruled out as the contributing factor. The very similar freeze tolerant genotype, Trichinella T6, has been identified in numerous geographical localities within North America including the United States; however, the multiplex PCR banding pattern clearly delineating the Trichinella T6 genotype was not observed in any of the analyzed samples. Previous studies have demonstrated T. nativa infections in a wide variety of mammalian hosts in the arctic and subarctic zones of the Holarctic region where the January isotherm is lower than $-5^{\circ} \mathrm{C}$ (Kapel, 1997; Pozio et al., 1998; Murrell et al., 2000) but never this far south in North America. Furthermore, although the outbreak in Tennessee did not

Table 2

Serological responses and worm burdens in mice and pigs infected with T. nativa-Plymouth

\begin{tabular}{|c|c|c|c|}
\hline Pig (number/age) & Number of muscle larvae given per os & ELISA titers & $\operatorname{lpg}$ \\
\hline 1 (1 year) & 2500 & 0.920 & 0 \\
\hline 2 (1 year) & 2500 & 0.903 & 0 \\
\hline 3 (1 year) & 10000 & 0.922 & 0 \\
\hline 4 (1 year) & 10000 & 1.075 & 0 \\
\hline 5 (3 month) & 2500 & 1.102 & 0.05 \\
\hline 6 (3 month) & 2500 & 1.001 & 0.20 \\
\hline 7 (3 month) & 10000 & 0.998 & 2.2 \\
\hline 8 (3 month) & 10000 & 0.955 & 0.75 \\
\hline
\end{tabular}


originate from a bear killed in the United States, it nonetheless demonstrates one possible method for dissemination of the freeze resistant genotype(s) to more temperate localities.

Previous studies by Kapel et al. (1998), and Kapel (2000) demonstrated that the infectivity level of $T$. nativa for domestic swine is below that which poses a public health risk ( $>1 \mathrm{lpg})$. In addition, these studies observed high serum antibody responses to Trichinella $\mathrm{E} / \mathrm{S}$ antigens in all experimental groups, including pigs in which no muscle larvae were recovered. Similar antibody results were seen in the present study; however, recovery of viable ML above the level of public health significance was seen in one, 3-monthold pig given 10,000 ML. These data suggest that variability in exposure and resistance to T. nativa in domestic swine could result in pig infections with freeze tolerant species that could pose a public health risk, and that the level of pig resistance may be age related since higher infectivity rates were observed in younger animals ( 3 months of age) relative to older animals (1 year of age).

\section{Acknowledgments}

The authors wish to thank James McCrary, Shannon Benedetto, and Valsin Fournet for their expert technical assistance.

\section{References}

Dworkin, M.S., Gamble, H.R., Zarlenga, D.S., Tennican, P.O., 1996. Outbreak of trichinellosis associated with eating cougar jerky. J. Inf. Dis. 174, 663-666.

Gamble, H.R., 1996. Detection of trichinellosis in pigs by artificial digestion and enzyme immunoassay. J. Food Prot. 59, 295-298.
Gamble, H.R., Wisnewski, N., Wasson, D.L., 1997. Diagnosis of trichinellosis in swine by enzyme immunoassay, using a synthetic glycan antigen. Am. J. Vet. Res. 58, 1417-1421.

Kapel, C.M., 1997. Trichinella in arctic, subarctic and temperate regions: Greenland, the Scandinavian countries and the Baltic States. Southeast Asian J. Trop. Med. Public Health. 28 (Suppl. 1), 14-19.

Kapel, C.M., 2000. Host diversity and biological characteristics of the Trichinella genotypes and their effect on transmission. Vet. Parasitol. 93, 263-278.

Kapel, C.M., Webster, P., Lind, P., Pozio, E., Henriksen, S.A., Murrell, K.D., Nansen, P., 1998. Trichinella spiralis, T. britovi, and T. nativa: infectivity, larval distribution in muscle, and antibody response after experimental infection of pigs. Parasitol. Res. 84, 264-271.

Kapel, C.M., Pozio, E., Sacchi, L., Prestrud, P., 1999. Freeze tolerance, morphology, and RAPD-PCR identification of Trichinella nativa in naturally infected arctic foxes. J. Parasitol. 85, 144-147.

La Rosa, G., Marucci, G., Pozio, E., 2003. Biochemical analysis of encapsulated and non-encapsulated species of Trichinella (Nematoda Trichinellidae) from cold- and warm-blooded animals reveals a high genetic divergence in the genus. Parasitol. Res. 91, 462-466.

Malakauskas, A., Kapel, C.M., 2003. Tolerance to low temperatures of domestic and sylvatic Trichinella spp. in rat muscle tissue. J. Parasitol. 89, 744-748.

Murrell, K.D., Lichtenfels, R.J., Zarlenga, D.S., Pozio, E., 2000. The systematics of the genus Trichinella with a key to species. Vet. Parasitol. 93, 293-307.

Pozio, E., La Rosa, G., Rossi, P, Murrell, K.D., 1992. Biological characterization of Trichinella isolates from various host species and geographical regions. J. Parasitol. 78, 647-653.

Pozio, E., Miller, I., Jarvis, T., Kapel, C.M., La Rosa, G., 1998. Distribution of sylvatic species of Trichinella in Estonia according to climate zones. J. Parasitol. 84, 193-195.

Pozio, E., 2001a. Taxonomy of Trichinella and the epidemiology of infection in the Southeast Asia and Australian regions. Southeast Asian J. Trop. Med. Public Health 32 (Suppl 2), 129-132.

Pozio, E., 2001b. New patterns of Trichinella infection. Vet. Parasitol. 98, 133-148.

Zarlenga, D.S., Chute, M.B., Martin, A., Kapel, C.M., 1999. A single, multiplex PCR for unequivocal differentiation of all encapsulated and non-encapsulated genotypes of Trichinella. Int. J. Parasitol. 29, 1859-1867. 